\title{
On the development of the caryopsis.
}

\author{
RODNEY H. TRUE. \\ WITH PLATES XXIV-XXVI.

\section{Historical.}

The structure of the fruit of the grasses seems to have received little attention prior to the beginning of the present century. During this period of increased interest in plant anatomy, some study was given to the structure of some of the commonest grains and even at this early date many observations were made that stood unquestioned until the last decade. Especially notable was the work done by Mirbel. He described for the first time the fruit of the Gramineæ and applied to it the name "cerium". " His definition was as follows: "A fruit in which, toward maturity, the ovary walls become united with the integuments of the seed. Richard ${ }^{2}$, at a later date, gave the name of "caryopsis" to the same fruit defined in a similar way.

The researches of Schleiden ${ }^{3}$ published in 1837 and in 1850 dealt with the fruit of the rye, Secale cereale L. In the earlier publication, the development of the grain was considered.

In I870, Anton Nowaki ${ }^{4}$ gave a condensed developmental history of the wheat grain and its envelopes.

In $\mathrm{I} 875, \mathrm{~F}$. Kudelka published ${ }^{5}$ the most complete account of the structure and the development of the common grains that had yet appeared. He described in great detail the development of the fruit of the rye from the time of the blooming of the flower to that of the ripeness of the seed. The general conclusions reached are substantially as follows: "Nie fehlende Schichten der Frucht- und Samenschale der Gramineen sind folgende: Die äussere Epidermis des Fruchtknotens, ein Theil des Parenchyms der Fruchtknotenwand, das innere Integument und die Epidermis des Knospenkerns.

In Folge von starkem Wasserverlust und Druck zur Zeit der Reife ist der innere Bau der Frucht- und Samenschale oft nicht deutlich erkennbar. Zusatz von Kali, wobei das betreffende Präparat aufquillt und dadurch mehr dem Stadium

${ }^{1}$ The index numbers refer to numbered titles in the bibliography at the close of this paper. 


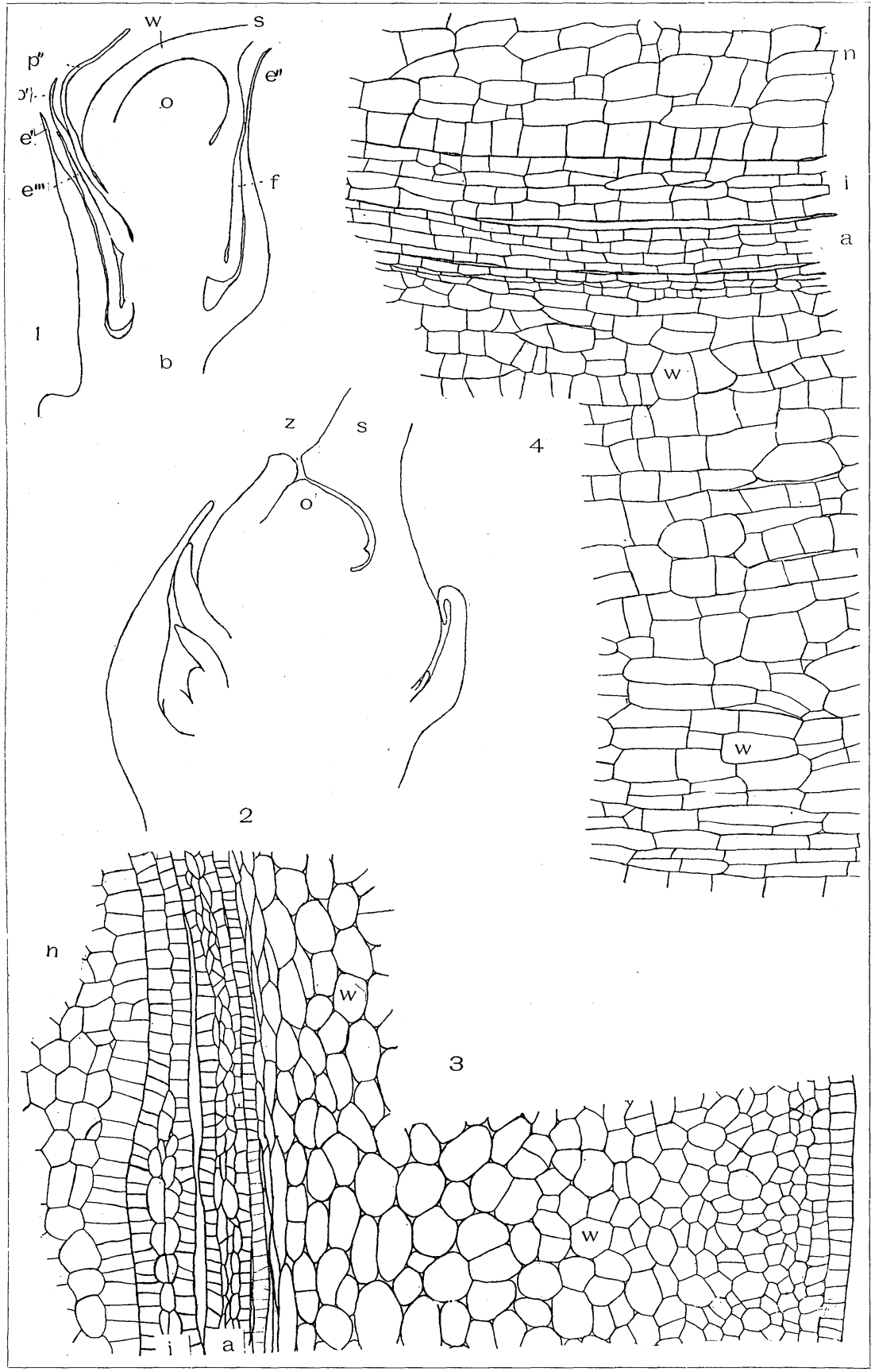

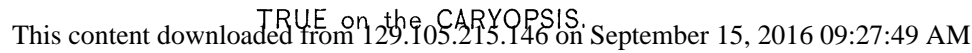
All use subject to University of Chicago Press Terms and Conditions (http://www.journals.uchicago.edu/t-an 


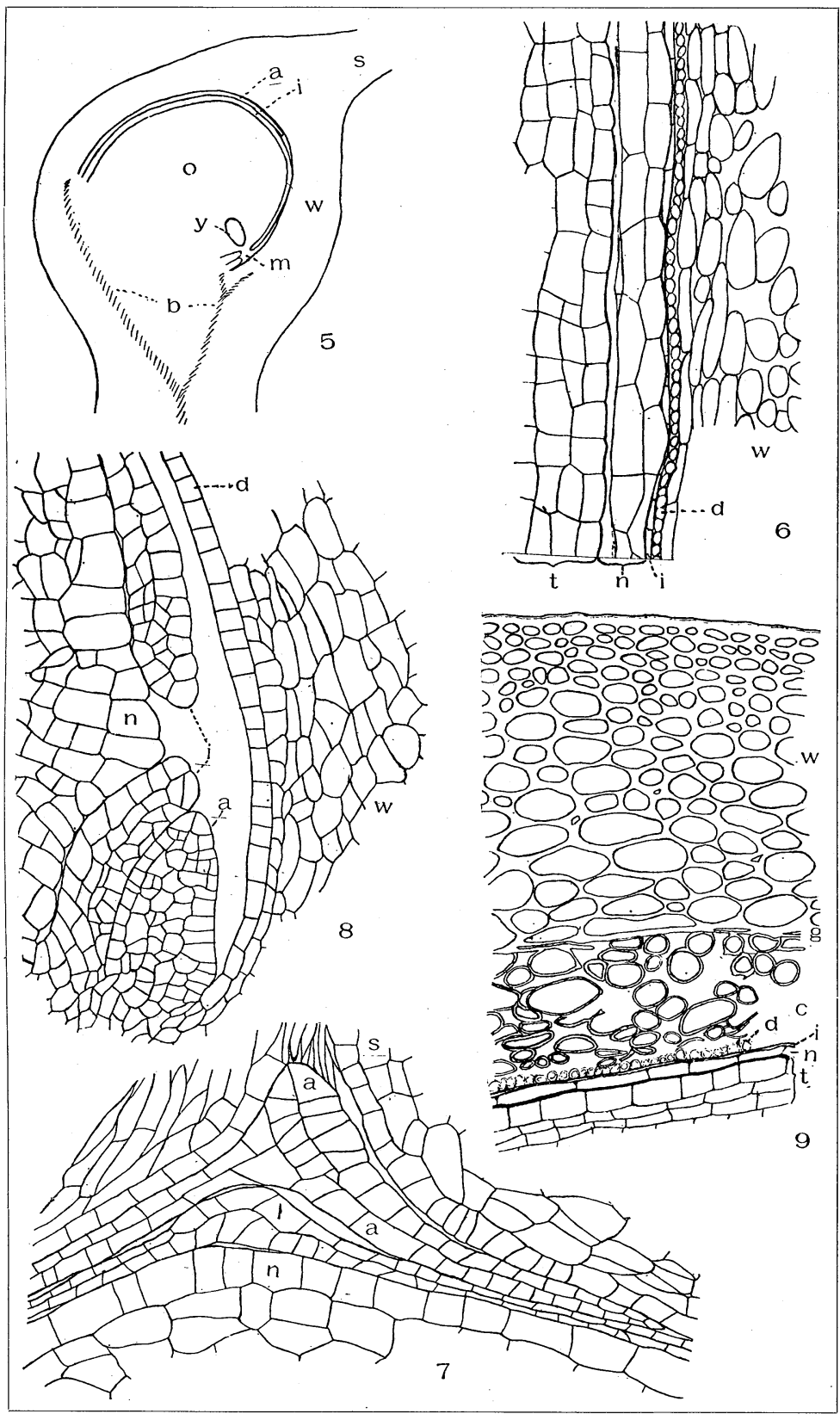

TRUE on the CARYOPSIS

This content downloaded from 129.105.215.146 on September 15, 2016 09:27:49 AM All use subject to University of Chicago Press Terms and Conditions (http://www.journals.uchicago.edu/t-an 


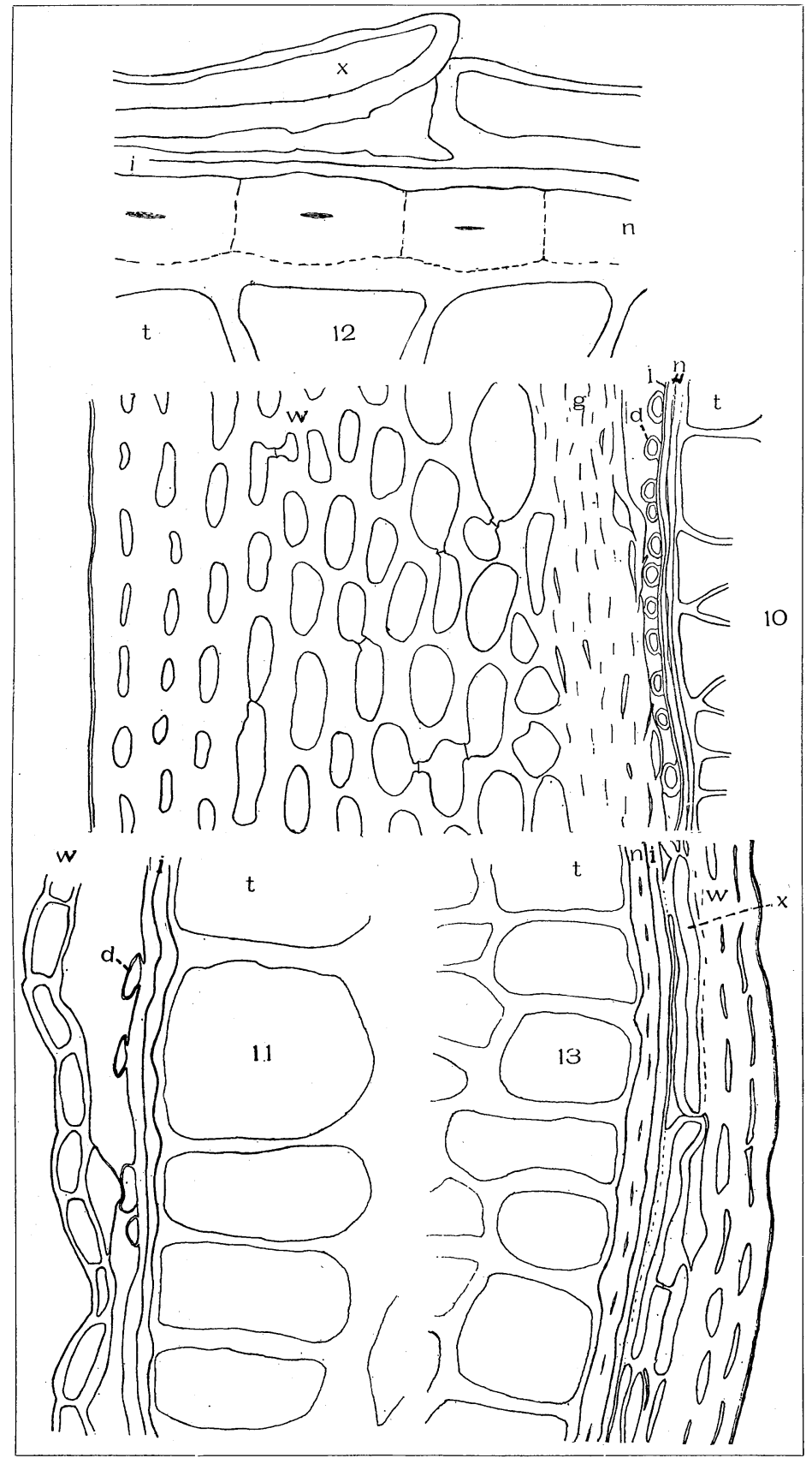

TRUE on the CARYOPSIS.

This content downloaded from 129.105.215.146 on September 15, 2016 09:27:49 AM All use subject to University of Chicago Press Terms and Conditions (http://www.journals.uchicago.edu/t-an 
der Milchreife ähnlich wird, ist durchaus erforderlich zur genaueren Betrachtung der einzelnen Schichten." The descriptions were accompanied by a number of plates. The most important literature on the subject was critically reviewed in the light of his results. To this review, I am indebted for the résumé of a number of early articles to which I have not had access.

W. Johannsen brought out in $1885^{6}$ the results of his study of the development and constitution of the endosperm of the barley. Although not included in his main subject of study, he gave attention to the fruit envelopes. In minor details only did he depart from the results previously obtained.

In I $888, \mathrm{H}$. Jumelle published ${ }^{7}$ the results of his investigations concerning the constitution of the caryopsis. As his conclusions differed very widely from the hitherto generally accepted view, I quote them. "A aucun moment, pendant la maturation du grain des Graminées, il n'y a soudre entre les téguments de la graine et le péricarpe. Le péricarpe se résorbe en partié; les téguments de la graine disparaissent complétement. Le fruit des Graminées ne mérite pas un nom spécial; c'est un akène renferment une graine sans tégument." Detailed observations on the wheat were given in the article, but other cereals were studied and all contributed to the results quoted.

In the same year, the same conclusions were announced in an article of wider scope. ${ }^{8}$

A. Zoebl made an investigation in $1889^{\circ}$ of the structure of the envelopes of the seed of the barley, Hordeum distichum L. After describing in detail the structure of the outer envelopes, the seed coats in the mature specimen were described in substance as consisting of two layers of cells united without spaces. The outer is much heavier than the inner which is often described as the "hyaline layer."

The latest reference to the subject that has come to my notice is found in Van Tieghem's Traité de Botanique, where I find this statement: "Chez les Graminees, le tégument externe de ovule est resorbé comme le tégument interne, et la membrane des sac embryonnaire vient s'accoler intimement contre le face interne des pistil. La graine y est depourvue du tégument." 10

I6-Vol. XVIII. - No. 6. 


\section{Introductory.}

The question involved in these discussions is one of some importance. The existence of the caryopsis as a type of fruit distinct from the achene has not been challenged, so far as I have been able to learn, until I 888 by Jumelle in the above cited articles. The adoption of his view and the incorporation of it into so important a treatise as that of Van Tieghem is likely to lead to confusion. To determine whether the earlier and accepted view or that of Jumelle is correct has been the object of this investigation.

To this end a careful study has been made of the history of every part concerned from the time of the fertilization of the ovule to that of the complete ripening of the seed in the corn (Zea Mays L.), wheat (Triticum vulgare Vill.), and the oat (Avena sativa L.). As the developmental history of the fruit of the corn has received less attention heretofore than that of the other common cereals, I have described it with some detail. The wheat and oat receive briefer mention.

The grains used were collected from fields near Baraboo, Wis., during the summer and fall of 1890 . The material used was gathered at suitable stages of development from plants of typical growth, and while fresh was immersed for from twelve to twenty-four hours, according to its bulk, in a solution of chrom-acetic acid. The following proportions by volume were used: saturated solution of chromic acid, 3 parts; acetic acid, 7 parts; rain water, 990 parts. To enable more rapid and complete penetration of the tissues of the corn to take place, the young axes were cut into small pieces. From the acid the material was transferred to weak alcohol after the removal of the surplus acid by thorough and repeated washing in rain water. After gradual hardening in alcohol of increasing concentration it was placed in commercial alcohol for permanent preservation. The younger stages were imbedded in paraffin and serial sections were cut with the microtome. Older grains were cut free hand. The use of potassic hydrate was found advantageous in studying much compressed tissues to swell them.

\section{Zea Mays L.}

At the time of the maturation of the egg apparatus, the ovary is unsymmetrical in form, being bent from the perpendicular in such a manner as to cause the long style, or "silk" 
of popular phrase, to point in the direction of the end of the spongy, club-shaped axis, the cob, fig. I. At this stage, the ovary is about $2.5^{\mathrm{mm}}$ long and at the point of greatest width, the base, has a diameter of about $3^{\mathrm{mm}}$. It is raised on a thick pedicel about $2.5^{\mathrm{mm}}$ in height. Attached to the sides of this pedicel and wrapped up closely about the ovary so as to nearly cover it, are the glumes and palets in the form of more or less fleshy scales. These parts occupy the characteristic positions in the flower. The two broad, fleshy outer glumes with fimbriated edges cover the more delicate flowering glume on one side and the third empty glume and the two palets on the other. The single ovule is attached by more than a third of its circumference directly to the floor of the ovary. The funicle is, therefore, not present. The ovule is very large and nearly fills the cavity of the ovary. Its form, like that of the ovary, is unsymmetric being so strongly curved as to be decidedly campylotropous. At this stage, the integuments of the ovule are fully developed, fig. 5. The micropyle is situated on the side adjacent to the flowering glume just above the point of attachment. The outer integument is incomplete, failing to cover an area extending from the micropyle to the base of the style, in length, and in width equal to about one-half the diameter of the ovule. It is present between the micropyle and the base of the ovule in the form of a short tongue-shaped projection. The inner integument forms a complete covering except at the micropyle.

The wall of the ovary at this stage attains a greater thickness than at any other time in its history, its average thickness being about $0.4^{\mathrm{mm}}$. It is bounded externally by an epidermis composed of cells containing large nuclei. The parenchyma forming the bulk of the wall consists of rounded and short-prismatic cells. In the outer third of the wall, the cells are much smaller and more elongated than those of the deeper parts. Hence intercellular spaces while very rare in the former region, are abundant and large in the latter. The cells of the inner two-thirds are large, rounded and necessarily more loosely arranged. The dividing line between these regions at this stage is not sharply defined, but later becomes very evident. Adjacent to the inner epidermis are two or more layers of small cells which are elongated in a direction transverse to the longitudinal axis of the ovule. The inner epidermis consists of small, nearly cubical cells. 
Over the greater part of its surface, the outer integument is in contact with the ovary wall. Figs. 3, 4.

In a considerable number of specimens, a pit was observed a short distance from the base of the style, on the posterior side. In some cases the depth of the pit at this stage was equal to one-half the thickness of the ovary wall. The edges were rounded and complete, showing that this space was due to a failure of the parts to unite completely. In younger specimens in which the embryo-sac had not yet developed, this pit was generally to be found. In many of these cases, the pit extended entirely through the ovary wail exposing the already developed outer integument. It seems that at this stage of development, the edges of the carpel have not yet completely united. Fig. 2.

The outer integument is, in the main, four layers of cells in thickness. Toward the top of the ovule it is reduced to two layers, except at the base of the style where it is thickened into a broadly wedge shaped mass which projects for a short distance into the base of the style, fig. 7. The short portion projecting over the anterior face is terminated by a single layer of wedge shaped cells. This integument is for the greater part in close contact with the ovary wall on the outside and with the inner integument on the inner side, but anterior to the base of the style there is often a considerable space between it and the ovary wall. As this region is traversed by the descending pollen tube, it is possible that it may aid in determining its course. The cells constituting this integument are generally short-prismatic, rather regular and have very thin walls, figs. 3,4 . The short wedge-shaped portion found below the micropyle is in close contact with a similar part of the inner integument, but is removed from the ovary wall by a considerable space, fig. 8 .

The inner integument varies in thickness from four layers of cells near the base of the ovule to two toward its apex. The cells as in the outer integument are short-prismatic in form but are considerably larger. The inner integument is closely in contact with the nucellus. At no points are the integuments strictly united with any of the adjacent organs save only at the points of their origin. At intervals, narrow spaces may be seen between adjoining structures. The function ascribed to the integuments seems to be that of protection to the parts enclosed. Holzner ${ }^{11}$ regards it as probable that they 
serve in some degree to give direction to the pollen tube. Hackel $^{12}$ says that the outer integument of the ovule of the Gram neæ "has very delicate walls, and forms a conductive tissue for the pollen tube upon the anterior side." Figs. 3, 4.

The nucellus consists of large isodiametric cells with small nuclei and scant contents. It is bounded by an epidermis with strongly cutinized outer walls. This cuticle is conspicuous in all stages of growth by reason of its great affinity for staining fluids. Toward the base of the nucellus, in its anterior part is found the embryo sac. In this grain it is very large, being readily sectioned even by free-hand methods.

For a very short time after fertilization no general change is noticeable in the ovule outside of the embryo sac. As the embryo and endosperm increase in size, they begin to exert a pressure on the adjacent tissue of the nucellus. Signs of yielding begin to be manifest here soon. Even earlier, in fact shortly after fertilization, the outer integument begins to show signs of weakening at the apex of the ovule near the base of the style. Soon after, the walls of the cells toward the outer surface of the young pericarp begin to thicken, especially those adjacent to the epidermis. The disintegration of the outer integument proceeds now more rapidly and it becomes increasingly difficult to detect the cell walls owing to their partial absorption and collapse. The first point of complete disappearance is at the apex of the ovule.

Previous to the collapse of the outer integument, the inner integument shows little change. Shortly, however, a slight tendency to weaken is seen, especially in the external layer of cells. In many the partitions become wrinkled. That a considerable pressure is exerted from within, is shown by the close contact of the inner integument with the ovary wall in places where the outer integument has disappeared. The nucellus is forced to undergo increased compacting to make room for the growing embryo and endosperm.

At a somewhat later stage, profound changes in the pericarp begin to manifest themselves. Toward the top of the ovule, the large-celled, thin-walled parenchyma of the middle and inner parts of the ovary wall begins to weaken and a crumpling or collapse, together with a compacting, of the cell walls becomes conspicuous. The outer boundary of the region in which this change takes place, is rather regular and is very 
definite. It extends nearly parallel to the inner epidermis at a distance from it of about one-third the thickness of the ovary wall. Fig. 9.

As a result of resorption, the rounded cells within this region are freed from each other leaving the original tissue represented by a stratum of detached cells. Absorption may go further leaving but indistinct remnants of some of the cells themselves.

This disintegration affects in less degree the inner epidermis and the adjacent elongated cells. The combined influences of partial disintegration and of pressure transmitted from the growing embryo separate the epidermal cells laterally. As a result, instead of forming a sheet, the epidermis has come to consist of ribbons of cells attached by their ends alternating with narrow spaces of approximately equal width. In short, the deeper tissues of the ovary wall in the region of the apex of the ovule have undergone a more or less complete disintegration. The walls of the outer epidermal cells and a few layers of cells beneath it, show some thickening, and in the walls of the latter cells, pits are noticeable.

At this stage the outer integument has entirely disappeared, fig. 6. The cell walls of the inner integument begin to weaken and collapse, but the layer can be easily seen in cross sections. Of the nucellus only two or three layers of cells remain except at the base of the ovule, where a considerably thicker and much compacted body of cells is found. The greater part of the missing tissue has been absorbed, but evidence of compression is found in the form of collapsed cells adjacent to the endosperm and embryo.

The cells of the endosperm are very thin walled and contain large nuclei and granular protoplasm. The peripheral cells are smaller and richer in protoplasm than those of the interior parts, the latter containing large vacuoles. The cells of the embryo are smaller than those of the endosperm and are in an active state. The use of proper stains brings out well the details of nuclear division in these cells. Even at this early stage the glandularlayer is distinctly differentiated as small epidermal-like superficial cells.

As development continues the modifications indicated in earlier stages become more and more pronounced. The thickening of the walls of the outer epidermis of the ovary 
and the underlying parenchyma continues; the disintegration in the inner parts extends toward the base of the ovule on all sides and becomes more nearly complete. The strips of cells representing the inner epidermis become more widely sundered.

For the most part the inner integument suffers compression of its elements and can be distinguished with difficulty. Of the nucellus nearly all the cells suffer absorption. An exceptional region is seen at the base of the ovule. Here a considerable quantity of the compressed tissue remains, persisting, in fact, even in the mature fruit. The epidermis of the nucellus with the strongly cutinized outer surface resists absorption, and although suffering compression may be readily recognized by the deeply stained cuticle.

The endosperm cells begin to assume their characteristic appearance. The aleurone layer contains abundant protein grains and the thickening of its cell walls is noticeable. The interior cells contain a few starch grains of the usual size and many smaller granules. The cell nuclei are still present.

From this stage to that of ripeness, the change is quickly made. In the mature grain the walls of the outer epidermis of the pericarp and the underlying parenchyma are so strongly thickened that the lumina are almost reduced to lines, fig. IO. The pitting of the walls is rendered conspicuous by treatment with a 5 per cent. solution of potassic hydrate. A distinct cuticle bounds the epidermis, but the underlying walls are rarely cuticularized.

Between the outer intact part of the ovary wall and the inner disintegrated region, lies a narrow line of compressed cells and débris. This compression seems to be the result of the outward pressure exerted by the growing embryo and endosperm. The resorption of the inner parts progresses until few or no detached cells or walls or remnants remain. There is thus formed an irregular cavity bounded externally by the jagged line of compacted remains and bounded internally by the sundered parts of the inner epidermis and the inner integument. As the growth within continues, this jagged gap is lessened in width until in the mature grain the limits come to lie adjacent to each other, fig. IO. In places, the inner epidermal cells are in contact with the line of compacted cells. In the mature grain, the lumina of these compacted cells appear to be mere striations and the limits of the individual cells are visible only upon treatment with potassic hydrate. 
In places, small portions of the inner epidermis seem to have been resorbed, but generally its separated elements persist and become united to the adjacent inner integument. This union is distinctly seen under high magnification after treatment in warm potassic hydrate. This soldering together of ovary wall and integument takes place late in the history of the fruit, probably after the "green-ripeness" of Kudelka. Occasionally cells of the inner epidermis are found soldered to the compacted cells of the ovary wall indicating that the union took place after the two tissues had been brought near together. As a result of compression and resorption, the ovary wall having an average thickness of about $0.4^{\mathrm{mm}}$ at the time of flowering has been reduced to a thickness of about o. $145^{\mathrm{mm}}$ in the ripe fruit.

In a ripe grain, the inner integument is visible only after treatment with potassic hydrate, and then in radial and cross sections of the grain as a line only. In tangential sections only is its cellular structure distinguishable. In close contact with it is the epidermis of the nucellus. This is likewise strongly compressed but the lumina of its cells can be detected after treatment with potassic hydrate. In stained sections the cuticle is conspicuous. At the base of the seed may be seen a considerable mass of the nucellus tissue. This is distinctly visible to the unaided eye as a small area of whitish color near the point of attachment of the seed. The aleurone layer has very strongly thickened walls at maturity which are found to be beautifully stratified after treatment with potassium hydroxide. At ripeness, the cells of this layer are closely packed with their characteristic contents. The interior cells of the endosperm have thinner walls and are closely packed with food materials consisting in the main of starch.

\section{Triticum vulgare Vill.}

As the developmental history of the wheat and of the rye has been described with a greater degree of completeness than the corn, I shall here give very briefly the results reached in the study of the wheat.

At the time of the maturation of the ovule, the ovary is broadly conical in outline with the apex directed downward. The posterior side is traversed for nearly its entire length by 
a groove which marks the position of the fibro-vascular bundle and also shows in a general way the position and extent of the attachment of the ovule to the ovary. The broad upper part of the ovary is thickly beset with rather coarse hair-like trichomes. The ovule is strongly campylotropous, being attached along its side to the ovary, carrying the micropyle at the lower end.

The ovary wall is of irregular thickness, in general becoming thicker toward the top of the ovary. It consists of an outer epidermis, many layers of rounded parenchyma generally looser in the deeper parts of the wall than near the outer epidermis, a single layer of cubical chlorophyll-bearing cells and a delicate inner epidermis. Near the furrow, the chlorophyll-bearing cells may frequently form a double row.

The integuments arise along the posterior side of the ovule and are complete except at the micropyle. They each consist very uniformly of two layers of cells with delicate walls. The enclosed nucellus is of a somewhat conical outline and is composed of the characteristic thin walled parenchyma tissue bounded by a distinct epidermis. The integuments are in contact with the ovary wall, with the nucellus and with each other, but at this stage are not structurally connected.

After fertilization the first marked change is the weakening of the elements of the outer integument. They become gradually more and more indistinct until the integument disappears entirely. In the ovary wall, the first change is seen in the parenchyma just external to the chloropinyll-bearing layer. A broad zone of this tissue is gradually absorbed leaving the outer epidermis and from two to four layers of the underlying parenchyma still intact. The inner epidermis also gradually disappears either completely or in great part. The nucellus as a matter of course undergoes very early changes. The cells about the young embryo and endosperm are compressed and resorbed to make room. These changes in the various parts proceed with considerable rapidity.

As the fruit develops, the processes of modification above mentioned continue. The chlorophyll cells elongate tangentially and assume a somewhat canoe-shaped outline when seen in cross sections of the grain. The cells lose their chlorophyll and the walls become strongly thickened and conspicuously pitted. Of the inner integument, both layers 
of cells persist. As development goes on, the outer layer becomes inconspicuous on account of the obliteration of the cell lumina and the almost hyaline appearance of the walls. The inner layer suffers less compression usually on account of the thicker walls, but often treatment with potassic hydrate is necessary to bring out the elements. With the exception of the region near the fibro-vascular bundle and the epidermis, the nucellus is eventually all resorbed. The epidermis persists in a compressed condition.

At maturity, the ovary wall outside of the chlorophyll layer consists of two or three rows of cells with strongly thickened walls and narrowed lumina, fig. I 3. The space formerly occupied by the absorbed portion of the wall has been filled by the outward movement of the inner growing parts thus bringing the chlorophyll layer in contact with the remaining cells of the ovary wall. The remaining cells of the inner epidermis, when present, and, in their absence, the former chlorophyll-bearing cells, are soldered to the hyaline outer layer of the inner integument and sometimes also exteriorly to the adjacent cells of the wall. Of the existence of this union, I think there can be no doubt. The inner integument, said by Jumelle to be absent, was present in every specimen I have examined and is plainly distinguishable under moderate magnification in specimens that have been treated with potassic hydrate. The hyaline outer layer is not easily demonstrated, but the thicker walled inner layer is readily seen, fig. I 2 .

In "red" wheats, particularly, this is true, since in the cell cavities of this layer is deposited a quantity of rusty red coloring material that catches the eye at once. The difference in color between the so-called red and white wheats depends on the presence or absence of this coloring matter in the inner integument. As far as I have been able to ascertain, this layer of cells is always present in the white wheats but is less conspicuous than in the red.

Thinking that possibly a difference between American and European varieties might account for the different results I have reached from Jumelle, I obtained through the kindness of the Department of Agriculture a number of specimens of European wheats which I examined with this possibility in mind. These however exhibited the same structures as 
already described. I am therefore compelled to dissent from Jumelle's conclusions, which Van Tieghem has adopted in his voluminous treatise.

The epidermis of the nucellus is seen in mature specimens after treatment with potassic hydrate, but with well nigh obliterated lumina, fig. I 3 .

\section{Avena sativa $\mathrm{L}$.}

At the time of flowering, the ovary of the oat differs in appearance from that of the wheat chiefly in the more complete covering of hairs. As development proceeds, however, other and more fundamental differences appear. Owing to the assumption by the bracts of the protective function, the pericarp is thinner and more delicate than in the grains described above. Resorption of the ovary wall goes further than in the corn and wheat, fig. I I. The chlorophyll cells as well as the inner epidermis and a greater part of the ovary wall disappear. As a result, in the ripe fruit, the pericarp comes to consist of the outer epidermis and a layer or two of adjacent interior cells only. As in the wheat, the outer integument disappears and the inner persists. It is very delicate, however, and in the ripe fruit reveals its structure only upon treatment with potassic hydrate. In fig. I I the layer adjacent to the endosperm is the epidermis of the nucellus. The inner integument, $i$, includes only the layer external to this.

The soldering of adjacent elements of integument and pericarp takes place less freely than in the corn and wheat. Owing to the great absorption of the tissue of the ovary wall, the remaining part comes to approach somewhat the condition of the loose utricular covering. As growth from inside progresses, the integument approaches this loose remnant, and in places eventually comes in contact, but never so closely as in the wheat. As a result, the pericarp is soldered to the integument at fewer points and is removed with less difficulty. The epidermis of the nucellus persists, but is plainly distinguishable only after treatment with potassic hydrate.

Some other fruits of the Gramineæ were examined, but less carefully than those described above. The results obtained were in the nature of corroboration of the doctrine that the pericarp and integument unite in the fruit of the grasses. 
As further opportunity shall permit, it is my intention to examine at different stages of development the fruits of related plants to ascertain, if possible, how widely this history is the history of other forms.

\section{Summary.}

I summarize my results and conclusions as follows:

I. - In the corn, wheat and oat, at the time of fertilization, the single ovule is furnished with two integuments, which are more or less complete. As development proceeds (I) the outer integument soon disappears; (2) the inner cells of the ovary wall are absorbed in varying proportions; (3) the tissue of the nucellus is absorbed, with local exceptions.

II. - At maturity, these remain as seed coverings: (I) the external portion of the ovary wall, in varying proportion, forming the pericarp; (2) the inner integument persisting in a state of compression. The epidermis of the nucellus also persists, though much compressed.

III. - Late in the development of the fruit, the remaining (inner) integument becomes soldered to the adjacent inner cells of the pericarp forming the fruit correctly described by Mirbel under the name of "cerium," and rechristened by Richard the "caryopsis."

This investigation was pursued in the botanical laboratory of the University of Wisconsin, under the direction of Prof. Charles R. Barnes. For his kind suggestions and help I wish to express my sincere gratitude.

Madison, Wis.

\section{Bibliography.}

While the literature of the development of the grains and, in an incidental and general way of their coverings, is somewhat extensive, few papers give to the coats a detailed study. I have here listed only those writings which touch most dlrectly and definitely upon the subject in hand and such, therefore, as would be most useful for general reference.

I. Mirbel: Ann. Mus. Nat. XIII.

2. Richard, L.: Analyse des embryons et endorhizes.

3. Schleiden: Ueber die Bildung des Eichens und Entstehung des Embryo bei Phanerogamen. Nova Acta Leopoldinæ Carolinæ Academiæ. $\quad 1837$. 
4. Nowaki, Anton: Untersuchungen über das Reifen des Getreides, etc. Verlag der Buchhandlung des Waisenhauses. Halle I870.

5. Kudelka, F.: Ueber die Entwickelung und den Bau der Frucht- und Samenschale unserer Cerealen. Landw. Jahrbücher. I 875 , p. 46o. Published also at Leipzig in 1875 underthe same title as an Inaugural-Dissertation.

6. Johannsen, W.: Om frohviden og dens udvekling hos byg. I 885 .

7. Jumelle, Henri: Note sur la constitution du fruit des Graminées. Compt. Rend. CVII, 285.- Same abstracted in Just's Bot. Jahresber. I 888, 788.

8. Jumelle, Henri: Sur les graines à deux téguments. Bull. de la Soc. Bot. de France, I 888, p. 35--Abstract in Just's Bot. Jahresber. I888, p. 748.

9. Zoebl, A.: Der anatomische Bau der Fruchtschale der Gerste, Hordeum distichum L. Verh. d. naturf. Vereins in Brünn, XXVII (1889). 26. - Abstract in Bot. Centralb. I 890, p. I 79.

Io. Van Tieghem, P.: Traité de Botanique, I. 924. Paris, I 89I.

I I. Holzner: Bot. Centralb. XII (I882). IO7.

I2. Hackel, E.: True Grasses, translated by Scribner and Southworth. Henry Holt \& Co., N. Y. I 890.

Explanation of Plates XXIV-XXVI.-Abbreviations used: $a$, outer integument of ovul.e-b, pedicel bearing the flower (Fig. I); fibro-vascular bundle (Fig. 5.). - $c$, area of disintegration $-d$, inner epidermis of ovary wall.$e^{\prime}, e^{\prime \prime}, e^{\prime \prime \prime}$, empty glumes in order. $-f$, flowering glume. $-g$, line of compacting of cells in ovary wall. $-i$, inner integument of ovule. $-m$, micropyle. - $n$, nucellus. - 0 , ovule. $-s$, base of style - $t$. endosperm. - $w$, wall of ovary. $-x$, chlorophyll bearing layer of ovary wall. $-y$, embryo sac. $-z$, pit in ovary wall near base of style in young ovules

Plate XXIV.-Fig. I. Longitudinal antero-posterior median section through the ovary of the corn at the time of the maturation of the ovule. $\times 30$.

Fig. 2. Same view of the young ovary prior to the formation of the embryo sac showing the pit near the base of the style. $\times 45$.

Fig. 3. Transverse section through the median region of the ovary wall and integuments of the corn at the time of blooming. $\times 325$.

Fig. 4. Longitudinal view of the same parts at the same stage. $\times 325$.

Plate XXV.-Fig. 5. View of the ovary and contents of the corn seen in median longitudinal antero-posterior section. $\times 45$.

Fig. 6. Longitudinal section of the inner coverings of the ovule of the corn. Disintegration appears in the ovary wall, the outer integument has disappeared and the nucellus suffers compression. $\times 325$.

Fig. 7. Antero-posterior longitudinal section of the integuments in the ovule of the corn showing the wedge-shaped thickening of the outer integument projecting into the base of the style. $\times 325$. 
Fig. 8. View of the integuments at the micropyle as seen in the longitudinal median section of the corn. $\times 325$.

Fig. 9. Transverse section of coats, etc., in the middle region of the ovule of the corn. The line of compacting in the ovary wall has formed, the innermost cells are freed, the inner integument is compressed, the epidermis of the nucellus remains. $\times 325$.

Plate XXVI.-Fig. Io. Transverse section of the coats of the corn grain at maturity after treatment with cold potassic hydrate. $\times 400$.

Fig. I I. Transverse section through the coats of the mature oat grain showing the union of the remaining cells of the ovary wall with the inner integument. The layer to the left of $i$ is the inner integument; to the right, the epidermis of the nucellus $\times 465$.

Fig. 12. Transverse section of the inner coverings of the mature wheat grain, showing union of the chlorophyll cells of the ovary wall with the inner integument after treatment with $\mathrm{KOH} . \quad \times 735$.

Fig. 13. Transverse section of the coverings of the mature wheat grain. $\times 465$.

\title{
Contribution to the biology of the organism causing leguminous tubercles.
}

\author{
GEO. F. ATKINSON. \\ WITH PLATES XII-XV. \\ [Continued from p. I66.] \\ Historical resume.
}

Early period of investigations.

The tubercles were at first supposed to be normal parts of the plants on which they were found. According to Vuillemin ${ }^{6}$, De Léchamp ${ }^{7}$ named the genus Ornithopus from the character of the tubercles and De Candolle ${ }^{8}$ uses the form of the tubercles as one of the characters of a variety of Ornithopus perpusillus.

Bivona $^{9}$ took them to be fungi of the genus Sclerotium and distinguished two types, the simple ones as $S$. lotorum and the lobed ones as S. medicaginum. Persoon's Sclerotium rhizogonum ${ }^{10}$ was also founded upon certain of these tubercles. Fries $^{11}$ rejects Persoon's S. rhizogonum referring the forms on

${ }^{6}$ Les tubercles radicaux des Légumineuses. Ann. d. Sci. Agronom. franc. et etrang. I 888 . p. 96.

${ }^{7}$ Histoire générale des plantes. I6 5 .

${ }^{8}$ Prodromus Syst. Nat. Reg. Veg. II (I825). 3 I 2.

${ }^{9}$ Pugill. plant. rar., Siculæ, IV. 26.

10 Traité sur les champignons comestibles, Paris. 1818.

11 Systema Mycologicæ, II. 250. 